This is an Accepted Manuscript of an article published by Taylor \& Francis Group in Policing and Society on 8 Apr 2016, available online: http://www.tandfonline.com/10.1080/10439463.2016.1165220.

\title{
"The Biggest Gang"? Police and people in the 2011 England riots
}

\author{
Tim Newburn, Rebekah Diski, Kerris Cooper, Rachel Deacon, Alex Burch and Maggie Grant
}

\begin{abstract}
Conflict with the police is a staple of civil disorder and the English riots of 2011 were no exception. The antagonism towards the police expressed by the rioters varied in intensity - from a low-level anger stemming from occasional negative experiences on the one hand to outright, visceral hostility on the other - but was visible everywhere riots took place. Leading politicians dismissed this hostility as nothing more than the typical wariness criminals have of the police. Indeed, it is undoubtedly the case that the police are an easy target for rioters seeking to explain away their conduct. Nevertheless, drawing on 270 interviews with people involved in the riots this paper shows that for some involved the police were a very deliberate and specific focus of anger and resentment. The basis of such feelings was complex and variable, but included historically poor relations between the police and particular communities, an inherited distrust of the police as an institution, to more particular and immediate experiences of mistreatment and prejudice - often coalescing around the perceived misuse of police powers such as stop and search.
\end{abstract}

Keywords: police, policing, riots, disorder, stop and search

\section{The police and riots}

By its very nature urban disorder involves conflict with the police. Crowds, intent on violent protest, or just intent on violence, destruction and the theft of property, must inevitably come into very significant confrontation with those seeking to prevent or control such behaviour. Or, put a different way, the 'police work at the heart of social conflict, and always will' (Fielding, 2005: xi). More than this, on occasion urban disorder may, seemingly, be provoked by police action and there are numerous examples of urban disorder where the police have themselves been the focus of crowd violence (Fogelson, 1968; Joshua and Wallace, 1983; Keith, 1993; Roche and de Maillard, 2009). The 2011 riots in England, like much disorder in the previous decades, involved large-scale confrontation between rioters and the police service. Moreover, several analyses of the England riots have pointed to hostility toward the police as having been a significant contributory factor - among many - in the emergence and spread of the riots (Lewis et al, 2011; Morrell et al, 2011; Reicher and Stott, 2011). Indeed, by far the largest of these studies, Reading the Riots, conducted by the Guardian newspaper and the LSE, and which forms the basis for this article, drew very specific attention to the rioters' attitudes toward the police in its account of the events of August 2011. Indeed, the Guardian newspaper headline on its initial front-page coverage of the Reading the Riots research was 'Blame the police: why the rioters said they took part' (Lewis et al, 2011).

Predictably, and in many respects understandably, the political and police reaction to such a headline, and the message it appeared to convey was vociferously critical. The Home Secretary, Theresa May, responding directly to the Reading the Riots study, said "Frankly, I'm delighted that career criminals don't like the police, that they feel the police are always targeting them and, as one said, that the police are always "causing them hell". ${ }^{1}$ Leading police spokespeople dismissed the rioters' anger with the police as being a

\footnotetext{
${ }^{1}$ http://www.dailymail.co.uk/news/article-2074025/Theresa-May-tells-LSE-Stop-excusing-greedy-rioters-looking-
} 
straightforward post-hoc rationalization of their conduct. Sir Huge Orde, President of ACPO, said 'Criminals explaining their own criminality - there is a slight irony there... I am entirely unsurprised that people who were rioting chose to blame anyone or anything but themselves for their actions. ${ }^{2}$ Similarly, Simon Reed, vice-chairman of the Police Federation argued that 'It was just common criminals taking advantage of the situation for their own means... These people have been asked to give an explanation for their actions and to blame police is just the easiest thing to do. ${ }^{3}$ The repeated references to 'criminals' echoed the Prime Minister's characterization of the riots as 'Criminality, pure and simple, as well as the Home Secretary's early suggestion that gangs were a primary cause of the rioting. ${ }^{4}$ Indeed, there was little or no political appetite in the aftermath of the riots to inquire in any great depth into why such events might have occurred, what might lie behind them, and whether indeed these, like some previous riots, might have something important to say about the relationships between the police and particular local communities or sections of the population. Before turning to this question it is important, briefly, to consider what earlier research has to say on this subject.

It is common in writing - both popular and academic - about the immediate 'causes' of riots to use words such as 'spark' and 'flashpoint' to indicate an event or series of events that mark the shift from (relative) orderliness to disorderliness. Such words, and the metaphor that underpins them, suggest that there may be a variety of fairly deep and long-standing structural 'causes' linked to rioting (poverty and racism would be two examples) but that something else beyond these is required to provoke, incite or otherwise stimulate or enflame people into violent protest. The work both of sociologists (for example Waddington, 1992) and psychologists (Reicher, 1984; Stott and Drury, 2000) has highlighted the often critical role of the police in the emergence and spread of rioting. Waddington et al (1989) use the phrase 'flashpoints' and argue that incidents become 'flashpoints' not because they contain some inherent characteristics that lead inevitably to the breakdown of order, but rather that they are a precursor to riot as a result of the way they are interpreted at the time. As a consequence there are a great variety of matters that might be perceived as 'flashpoints' and this leads Waddington and colleagues to identify a series of 'levels' of analysis which range from the broad structural, political and cultural contexts in which conflict can arise, through to the situational and interactional features which are potentially important to understanding any outbreak of disorder.

In applying their model to the disorder in Bristol in 1980, Brixton in 1981 and Broadwater Farm and Handsworth, Birmingham both in 1985 they found that 'police-community relations had undergone a significant deterioration in the period immediately prior to the riots' (Waddington et al, 1989: 144). Subsequently they observed that 'direct or indirect police provocation of the crowd was... complemented by crowd provocation of the police' (Waddington et al, 1989: 145). Having studied a wide range of disorderly incidents they argue that their 'flashpoints' model is important because it helps identify policies that might enable future disorder to be avoided or mitigated. The most important of these policies, they argue, 'clearly lie in the area of political and economic justice but others centre on the role of the police as it affects communities in general and particularly around potential flashpoints' (Waddington et al, 1989: 152). Studies of riot 'flashpoints' regularly identify the police, and the actions of police officers, as a

instant-gratification.html\#xzz2xAHpb6Cu (accessed 27 March 2014)

${ }^{2}$ http://www.dailymail.co.uk/news/article-2070083/Police-fury-LSEs-bid-blame-summer-riots.html\#ixzz2xAJtCahn (accessed 27 March 2014)

${ }^{3}$ http://www.dailymail.co.uk/news/article-2070083/Police-fury-LSEs-bid-blame-summer-riots.html\#ixzz2xAJtCahn (accessed 27 March 2014)

${ }^{4}$ The suggestion was made in a speech to the House of Commons on $11^{\text {th }}$ August 2011, https://www.gov.uk/government/speeches/riots-theresa-mays-speech-on-11-august-2011 (accessed 23 December 2014) 
significant contributory factor in the escalation of activity toward disorder (see also King and Waddington, 2006; Body-Gendrot, 2013; Fassin, 2013). As they go on to observe, none of this is to blame the police for urban disorder or even to suggest that changes in police practices would, in themselves, necessarily solve the problems that give rise to rioting. Rather, it is to note that police conduct and policing practices are regularly to be found to be important features in understanding the etiology of urban disorder and it should be of little surprise to anyone seeking to analyse rioting that the public perceptions and experiences of policing come to play an important, if not necessarily the most important, role. Before moving on to the 2011 riots themselves, it is worth briefly reviewing some of the earlier and by now sizeable research evidence on policing and riots both in the UK and abroad.

\section{Anti-police sentiment and public disorder}

On both sides of the Atlantic over the past half-century, official inquiries into, and academic analyses of, major outbreaks of public disorder have regularly found anti-police sentiment to have played an important role in the actions of those involved. The Kerner Commission established by President Johnson in 1967 to examine the US urban riots of the 1960s remarked that 'the police are not merely the spark' (National Advisory Commission, 1988: 206). Rather, a 'deep hostility between the police and ghetto communities [was] a primary cause of the disorders surveyed by the Commission' (National Advisory Commission, 1988: 299). In the UK a number of commentators took the view that the urban disorders of the early 1980 s - both in 1981 and 1985 - were fundamentally 'anti-police riots' (e.g. Clare, 1987; Smith, 1987). Of these, Smith is careful to unpack this phrase a little, arguing that it is important to distinguish between the individual level' - how particular people experience policing - and the political or collective level where hostility towards the police among certain groups is the focus. What emerges from these and a wide variety of accounts in the period - from the St Pauls riot in Bristol in 1980 (Joshua and Wallace, 1983; Reicher, 1984) to the riots in Birmingham in 1981 and 1985 (Field and Southgate, 1982: King, 2013), across London in 1985 (Keith, 1993) and in Newcastle, Oxford and elsewhere in the early 1990s (Campbell, 1993) - is that tensions between the police and particular communities, particularly minority ethnic communities, were a significant element in the rioting.

A degree of caution is necessary here for at least two reasons. First, and as the Kerner Commission and most others have noted, even when there is significant hostility directed toward the police during urban violence this is rarely, if ever, the sole consideration in the minds of rioters (National Advisory Commission, 1968; Gilje, 1999). In this regard, Lord Scarman in his famous report into the Brixton riot of 1981 noted that two views about the causes of the riots were put to him by many giving evidence. One was that the riots were 'anti-police'. A second was that they were a form of protest by the socially and politically marginalised who used their attacks on the police as a means of drawing public attention to their wider grievances. To this he said, 'I have no doubt that each view, even if correct, would be an over-simplification of a complex situation. If either view should be true, it would not be the whole truth' (Scarman, 1982: 14).

The second major reason for caution here is the very clear danger of 'over-reading' social events such as riots. Prior to the 1960s much thinking about rioting and collective disorder tended to emphasise what it took to be the fundamental irrationality of such conduct (Tarde, 1903; for a discussion see Borch, 2006). 'Riff-raff' theories, associated in particular with the work of the French social psychologist, Gustave Le Bon, which emphasised the impulsiveness, suggestiveness and credulity of crowds (Le Bon, 1896), were dominant. Such views are now largely discredited (Stott and Reicher, 1998; Waddington and King, 2005). Partly as a consequence, both official inquiries and academic studies of riots since that time have tended to take a very different view and, in particular, have paid greater attention to the accounts rioters themselves give of their motivations for their conduct. Moreover, as P.A.J. Waddington (1994: 3) says: 
The political imperative for taking rioters seriously is clear: it counters the attempt by the political establishment to dismiss rioting as merely a lawless outburst and thus to discredit the grievances of ethnic minorities. Insisting that rioting is a form of political protest dignifies it and demands that the grievances of rioters be addressed.

Waddington (1991) nevertheless goes on to suggest that much work in this vein has been fundamentally flawed, in effect coming closer to 'advocacy' than 'analysis'. In particular, much academic work, he suggests, moves imperceptibly from documenting the existence of injustices in the lives of those engaged in rioting to using such injustices as an explanation for their conduct without explaining how the experience of such injustice becomes translated into action:

The claim that young Black people in inner-city areas suffer disadvantage, discrimination, and police harassment is treated, not as a belief, but as a fact. The task of analysis, then, is not simply to show how the belief mobilises collective action, but becomes instead a quest to reveal the injustices which substantiate the justifications for the riots. (Waddington, 1991: 246)

A social psychological literature has emerged which attempts both to theorise and to examine empirically how attitudes and beliefs are transformed during, and come to shape, riots and other forms of collective behaviour. Reicher and colleagues (Reicher, 1984; 1987; Stott and Reicher, 1998) argue that crowds act according to a shared social identity. The key components of this social identity (how the members of the crowd see themselves and others) influence the behaviour of the crowd by establishing normative limits to conduct and to participation. Where the 'flashpoints' model incorporates a wide-range of analytical 'levels', including the long-term historical, cultural, economic and political context within which rioting occurs, Reicher and colleagues 'elaborated social identity model' (ESIM), though acknowledging the importance of these, focuses more particularly on the more immediate interactional locus in which police and crowd (inter)actions effect changes in social identity among those present. The nature of the relationship between the crowd and, for example, the police, is dynamic and has the potential both to influence changes in selfcategorization and to lead to a sense of empowerment within a crowd.

Although, as outlined above, some combination of sociological and social psychological approaches offers the promise of understanding how the apparent frustrations and grievances held by members of a crowd become translated into violent and destructive action (or, alternatively, remain peaceful - see Newburn, 2015) it is always necessary to remain vigilant to the danger of over-rationalising the conduct of crowds, reading into it a set of political or other motives that, if present, are far from the entire explanation for the events concerned. As Rock (1981: 19-20) quite rightly observed of much writing in this field, there are occasions when 'it is as if riots cannot be innocent of profound meaning... very few have proposed that riots are not invariably intended to convey sober meaning and political lessons'. In examining the attitudes of rioters toward the police it is important, therefore, to recognise that because of their role and position the police will inevitably become something of a focus for the anger, the frustration and the violence of the rioters. The simple fact that the police are the most visible manifestation of the state leads them to become the institutional equivalent of a 'condensation symbol' (Edelman, 1964), effectively a lightening rod for broader grievances and concerns, and makes them a predictable and easy target. Moreover, and simultaneously, it is vital not to lose sight of the fact that the accounts of those involved may also be influenced by a desire to rationalise their behaviour - to utilise what, in other circumstances, have been referred to as 'techniques of neutralization' (Sykes and Matza, 1957). The analysis reported below has, consequently, attempted to remain alive to this danger and be particularly vigilant not to 'over-interpret' 
the accounts, statements and claims of those involved. Bearing these warnings in mind we now briefly consider our analytical method, before moving on to the 2011 England riots and, more particularly, what the rioters themselves had to say about the police and policing.

\section{Method and analysis}

The data utilised in what follows were drawn primarily from a research study called Reading the Riots, which was established and run jointly by the Guardian and the LSE (Lewis and Newburn, 2011), though information will also occasionally be utilized from other sources including official inquiries, Metropolitan Police survey data and other research. Reading the Riots had two phases, the first focusing on the rioters themselves, and the second looking more broadly at the criminal justice response to the riots. In the first phase $\mathbf{2 7 0}$ 'rioters' were interviewed - people from London, Birmingham, Manchester, Salford, Liverpool and Nottingham who admitted having taken part in the riots ${ }^{5}$ and, in the vast majority of cases, having not been arrested. A team of 30 interviewers was recruited by the Guardian/LSE, the individuals being drawn in the main from the cities, and often the particular neighbourhoods, affected by the riots. Interviewers used their own knowledge of these neighbourhoods, and their own contacts, together with local 'fixers', recruited by the newspaper, to seek out people locally willing to be interviewed. All interviewees were guaranteed anonymity, but no payments were made for the interviews given. Of the 270 respondents, 185 were interviewed in London and the remaining 85 in other cities where rioting occurred, including 36 in Manchester/Salford, 30 in Birmingham and 16 in Liverpool. Almost four-fifths (79\%) were male and 21\% female, a slightly higher proportion of females than appears in the arrest statistics for the riots (Home Office, 2011). Respondents were overwhelmingly young, 31\% being aged $10-17$ and $34 \%$ aged $18-20$. In terms of self-identified ethnicity, just under half of respondents described themselves as 'Black' or of mixed ethnicity ${ }^{6}, 27 \%$ as 'White', $19 \%$ as 'Mixed/Other' and 5\% as 'Asian'.

It is important to reiterate the point made earlier about 'involvement' in the riots. The vast majority of the 270 respondents talked explicitly about their participation in a variety of riot 'actions' including the violence, arson, protest, and the looting. Although it might be objected that there is no 'comparison group' of non-rioters in this study, the broad arguments that we develop below are supported by other (generally smaller-scale) research on, and analyses of, the riots, that did draw information from individuals and communities that were not involved in the riots (see Morrell et al, 2011; Riots, Communities and Victims Panel, 2012). In semi-structured, open-ended qualitative research interviews, lasting usually between 40 and 90 minutes, they were asked about their involvement in the disorder, including what actions they had taken, how long their participation had extended, their perceptions and motivations, together with a small number of closed questions at the end about themselves and their experiences and attitudes. Given the difficulties associated with 'post-hoc rationalisation' great care was taken to ensure that the interviews were conducted in a non-leading manner. In particular, given that our starting assumption - influenced by what research on earlier riots had shown - was that the police and policing might potentially figure quite markedly in rioters' accounts of both their experiences and their 'motivations' an explicit decision was taken to avoid any questions directly relating to the police. If, subsequently, during the course of interview respondents did raise the subjects of the police and policing our assumption was that this was,

\footnotetext{
${ }^{5}$ A small number of the 270 claimed only to have 'observed' the riots. In some cases this may have been the case; in others they were almost certainly involved but had decided, for whatever set of reasons, not to discuss their involvement when it came to the interview. Nonetheless, the vast majority of the 270 might reasonably be described as 'rioters'.

6 In this connection covering anyone self-describing as black/African/Caribbean/Black British
} 
consequently, likely to be a more reliable account than would be the case if such matters had been deliberately stimulated by the interviewers. ${ }^{7}$

Given the complexity of the data it was felt that the best way to uncover the perspectives of the rioters was to adopt an 'exploratory' or 'content-driven' approach, using thematic analysis as the basis for the inductive identification of key themes and sub-themes (Guest et al, 2012; and in the context of riots research: Stott and Drury, 2000). The focus was therefore not on the application of pre-defined codes and categories, such as in content analysis, but rather on ensuring that any findings were located in the textual data itself. Great care was taken to ensure the analysis was rigorous with any potential bias reduced, and particular attention was paid to developing strategies for monitoring and improving inter-coder analysis and, consequently, reliability. All interviews were fully transcribed and checked, and then read and re-read initially by a single analyst. Key themes were generated inductively from the transcripts, with an analytical team of five working separately but interdependently. Once a set of transcripts had been read and analysed by individual members of the team, they were then discussed across the group, comparisons and refinements made, and final decisions agreed collectively.

To ensure that the coding of the interviews was systematically carried out by all analysts, a proportion were cross-checked within the analyst team, with more than one analyst coding the same transcript separately (multi-coding) and then checking the results for inter-coder reliability. Adjustments both to decisions, and to the approaches taken by individual analysts could then be made. Each transcript was read, re-read and coded holistically with great attention to context and consistency throughout interviews, with the aim of getting as close to a faithful interpretation of respondents' answers as possible - answers that on the surface occasionally appeared contradictory. As suggested above, given the particular problem of post-hoc rationalization, great care was also taken to ensure that interviews were conducted in a non-leading fashion. On those occasions where it appeared answers in interview transcripts were potentially the result of a leading question, this material was highlighted on the transcript and not included in the collective analytical documents that were produced by the team. Again a system was devised to enable crosschecking for reliability and consistency and to ensure that decisions to include to exclude material were made uniformly. The outcome of this process was the construction of a series of spreadsheets in which illustrative quotes were taken from the individual transcripts and located under a series of headings corresponding to the 'themes' and 'sub-themes' generated by the analytical team. This then allowed members of the research team to be able to take a broad overview of the full, huge dataset. All quotes had individual identifiers so that the original could be easily and quickly checked in order that particular statements by respondents could be understood in the context in which they were made.

Those involved in the riots talked of a great many things: their anger and frustration with politicians and others in authority; their resentment at how they felt they and others in their communities were treated by the wealthy and powerful, and their day-to-day experiences on the streets (Lewis et al, 2011). Hugely prominent in their accounts was their relationship with the police, not just on account of their involvement in the riots but more generally, and it is to what 'rioters' had to say about the police that we turn next. The main strands of argument below connect with the themes that appeared most frequently and strongly in the qualitative analysis, and the quotes presented are those that best illustrate each particular theme.

\footnotetext{
7 Despite this the Daily Mail sought to challenge the credibility of the research by arguing that, to the contrary, the interviews conducted in Reading the Riots had been entirely leading http://www.dailymail.co.uk/debate/article2072228/Apologists-mob.html In the article the questions about policing noted by the Mail were all 'closed' questions asked of all respondents at the end of the otherwise open-ended interview.
} 


\section{The Shooting and its Aftermath}

Official accounts of the 2011 riots all tend to begin with the August $4^{\text {th }}$ shooting of Mark Duggan, a 29-year old Londoner from Tottenham, by Metropolitan Police officers from Operation Trident (MPS, 2012). A wide range of sources - including the local citizens' inquiry (North London Citizens, 2012), the local MP (Lammy, 2011), the Metropolitan Police's own review (MPS, 2012) and the House of Commons Home Affairs Select Committee (2011) all point to the shooting, as well as the rumours that circulated in its aftermath, and the handling of subsequent protests outside Tottenham police station in North London, as key events in the lead-up to the outbreak of disorder. Many of the respondents in Reading the Riots spoke of the anger around the shooting and talked of the disorder either as a release of anger and/or a form of protest:

It was to do with Mark Duggan. And it was to do with peaceful protest. And it was to do with the fact that we're fucking sick to death with the police just getting off with things. No-one was looting or doing anything. The whole neighbourhood was there. All the different ethnic groups were there...it wasn't organised gangs, it was a spontaneous thing.' [42 year old, white ${ }^{8}$ male, Tottenham, London]

I went out there to support the cause [for Mark Duggan], I didn't go out there to steal, I didn't go out there to commit violence I just wanted to be there to show that... yes I agree. [34 year old, Black British male, Tottenham, London]

It is important to remember that two days passed before rioting broke out in Tottenham and most accounts of the escalation of tension point to the way in which the protests in north London were perceived to have been mishandled by the police. Commenting on the general situation - including the failure properly to communicate with the local community, and particularly with Duggan's family - the Home Affairs Select Committee (2011: 7) said:

The death of Mark Duggan was a significant factor in the disorder that took place in Tottenham. In the event of a fatal shooting of a member of the public by a police officer, it is essential that the force concerned communicates swiftly with the victim's family. There is no excuse for confusion about whose role this should be: a family liaison officer should be dispatched immediately by the force in question. Until this has happened, no substantive public comment should be made, and the name of the deceased should not be released.

In rather different language, the Metropolitan Police Service's own review of its activities in the 48 hours after the shooting concluded that, despite the fact:

...that standard MPS good practice in relation to community engagement had been followed, the desired outcomes of gauging an accurate picture of community tension and working with the community to address such tension were not achieved. (MPS, 2012: 30)

As one interviewee, commenting on the initial stand off in Tottenham and the failure of the police to communicate with Mark Duggan's family and the protesters, put it:

\footnotetext{
${ }^{8}$ In all cases it is respondents' self-described ethnicity that is used.
} 
A little bit of politeness and etiquette would've easily squashed that situation. It's such a joke... the way the riot really got started was through the fact that there was nothing said. [23 year old, Black British male, Tottenham, London]

Whilst, perhaps understandably, many have pointed to the shooting as the 'flashpoint', it is clear that it was the wider perceived failures of police-community communication that fed into growing anger on the streets of Tottenham.

I was angry at the fact that, at the end of the day Mark Duggan's dead. And still no answers have been delivered. And now it seems like the whole objective of today is for [the police] to defend that police station, so it's not only that you don't care about lives of African-Caribbeans or in fact you just don't care about lives of people who fit a certain description in Tottenham, but now you're saying you just don't care what happens in Tottenham as long as your police station is safe. [ 25 year old, Black British male, Tottenham, London]

Some respondents, whilst recognising the relatively spontaneous and reactive nature of the disorder in the aftermath of the shooting and police station protest, made a link between this and a longer-standing disenchantment and discontentment:

Mark is like the trigger. But it's to do with the underlying problems, the cuts, the unemployment levels, it's the frustration of people, it's the police treatment of people, people just thought this is a chance to vent that frustration, and get their own back in a sense and a lot of people were there for that more than anything. [21 year old, White male, Tottenham, London]

Everyone's just been wanting to do something to the police for time, everyone, and then that's basically that was the trigger, the Mark Duggan, and then everyone thought right it's time to show them...the first two days everyone's tryna prove a message kind of thing. And then after that everyone thought free stuff, that's when it got out of hand...' [24 year old, White male, Lewisham, London]

This latter sentiment - that the initial disorder was clearly linked to the Duggan shooting and protest, but that much later activity was motivated by other factors - was clearly articulated by a number of respondents:

To the youth of Tottenham, it was for Mark Duggan; out of Tottenham I feel people were just taking the piss to be honest.' [20 year old, Black Caribbean male, Tottenham]

It was kinda insulting to Mark Duggan, when you think about it because like the Tottenham riots I can understand, then everyone doing it... everyone kind of missed the point that it was about Mark Duggan and not about like getting free stuff... people sort of forgot about it do you know what I mean?' [16 year old, mixed race female, Brixton]

In part what was being articulated here, it seems, was desire to see a distinction drawn between the initial protests (whether peaceful or not) and subsequent violence and looting. For some this undoubtedly reflected their belief that there were genuine differences in the nature of crowds present and their actions. For others, almost certainly, it reflected the hope that the legitimacy of the initial protests would not be undermined by the actions of rioters attacking the police and looting shops. Two initial points arise from 
this. First, it is undeniable that the shooting of Mark Duggan, the perceived mishandling of the subsequent protests, as well as broader underlying grievances, some of which focused on the police, all played a part in the rising tensions on display in Tottenham on the first evening rioting broke out. Second, even at this very early stage of the rioting, characterising either the 'crowd' or their motivations in a simple or straightforward manner as protesters venting anger or frustration about the Duggan shooting would be to over-simplify. In this regard, though there is not the space to explore it in detail here, it is important not to lose sight of the fact that there were significant differences in the nature of the 'rioting' in different locations within London, in different cities and on different days. In some places looting was more prominent, in others attacks on property or violence against the police predominated. As one example, officers from Greater Manchester Police, where there was rioting in both the city centre and in outlying Salford, reported very different experiences. As one officer put it:

Salford they were out to hurt the police-absolutely... In Manchester, it was less "have a go at the police" - they weren't really throwing as much at us-it was more "I can go and get myself a pair of Diesel jeans for nothing".

There was a strong feeling, expressed by many police officers, that whilst the initial rioting in London might realistically have involved an element of protest, it was harder to accept that this was the case the further away from London one moved and the greater the time that had passed. Indeed, the bulk of police officers described the last three days of rioting as predominantly opportunistic criminality. A minority of 'rioters' expressed similar views, and there can be little doubt that some of the later rioting - both the looting of shops and violence against the police - was broadly opportunistic in nature. However, to seek to portray it, as many politicians did, as nothing more or less than 'criminality' is to avoid confronting the complexity of the behaviour on display. Opportunistic some of it may have been, but that is not to say that it was absent of meaning. We have described elsewhere the complex motivations and meanings surrounding the looting during the 2011 riots (Newburn et al, 2015). In the case of the violence, particularly that aimed at the police, it too was often underpinned by strongly held feelings. Reflecting on this, another Greater Manchester Police officer, comparing Salford with the rioting in the city centre, felt his colleagues in Salford were:

...lucky to be alive because, I have no doubt, I mean, it was different in the city centre, the city centre was kids wanting to loot and ... cause....as much damage as they possibly can...Salford, you know, there's a real real hatred of the police. (emphasis added)

\section{Relations with the Police}

Whilst the shooting of Mark Duggan, and the handling of the protests in the aftermath, were mentioned regularly by respondents in north London, and to a lesser extent beyond, interviewees in all the cities in which the study was conducted talked more broadly about their generally negative attitudes toward the police. In many cases they argued that these attitudes were common to the communities in which they lived and, moreover, often had a long historical continuity to them. Some older interviewees remembered confrontation with police officers as an ordinary feature of childhood. A 43-year-old white man from Salford recounted regular violent encounters with police officers as a young person: 'I can only speak for Salford, it was rife you know, you grew up just hating police'. Accounts of overt police violence were not uncommon, but more prevalent was the insidious disrespect and sense of illegitimacy that framed policecommunity relations in some areas. Mirroring much extant research (Jackson et al, 2013; Sergeant et al, 2014), some respondents depicted a situation in which the complete absence of trust in the police as a 
protective force meant that people would not call them even if they were in need, as emphasised by this 50-year-old White man from Tottenham:

[P]eople don't report crimes to the police... they don't have the confidence that they're gonna help.... with any of the problems that they've got. So, nobody wants to bring the police in their area'.

In certain areas poor police-community relations were informed by an ingrained historical narrative of enmity, and were punctuated by violent confrontations and even riots. This was particularly true of Toxteth in Liverpool and of Tottenham and Brixton in London. In these areas, respondents' views on policecommunity relations were imbued with an understanding of the legacy that weighed on their communities. Some remembered the events that had marked relations over the decades, like this 49 -year-old Black woman from Tottenham:

I don't like the police, I've never liked them, I don't want to have no communication with them. The reason is what we had to go through in Broadwater Farm.

Others had inherited anti-police lore and accompanying distrust from older generations, as in the case of this 25-year-old black British man, also from Tottenham:

When we grew up in Tottenham we'd always hear you've gotta be cautious about the police. I was born in '86 so obviously the year before Cynthia Jarrett was killed in Tottenham so I heard from my family you gotta be wary of the police, people would get beaten up by the police and so forth... from that time we heard stories about Roger Sylvester, that kind of kicked off a lot of friction there, and then you had Mark Duggan it's like "alright...wow", it's like a slap in the face.

Whilst many of the police officers interviewed [total] were very sceptical that a shooting in north London could possibly be linked to riots in geographically distant locations and occurring one, two, sometimes three days after the initial disturbances, as the quote above illustrates, many respondents saw the shooting of Mark Duggan as the latest in a litany of unaccounted for deaths at the hands of the police. Respondents of all ages recited the names of Cynthia Jarrett (whose death from a heart attack during a police search of her house was one of the triggers for the 1985 Broadwater Farm riot; see Smith, 1991), Roger Sylvester (a 30-year old man from Tottenham with mental health issues who died whilst being restrained by six police officers; see Pemberton, 2008) and Joy Gardener (a 40-year old woman who also suffocated while being restrained by police officers; see Scraton, 2002) as evidence of perceived police injustice and their seeming impunity from the law. In this narrative, past riots were seen as both cultural heritage and legitimate reactions to the contempt with which the police were believed to treat the community. The conduct of the police towards Mark Duggan's family in the aftermath of his death, and the disorder that it sparked, was perceived as the most recent indicator that nothing had changed:

What's happening right now happened in ' $85 . .$. when my woman got killed... there were reporters coming talking to the people of Broadwater Farm sitting down, look, over twenty years later the same thing's happening' (black male, 16, Tottenham).

A number of interviewees, such as this 16 -year-old black young man from Tottenham, linked their participation in the riots directly to this stalemate: 
[T]hey always try and kill off young black people all the time. It's not the first time they did it and got away with it, that's why we done a riot to try and find out the information why they did it and what was the reason for.

Such views were expressed, about alleged police misconduct and an apparent lack of accountability were expressed in all the cities in which major rioting took place. Having lived through or grown up with stories of previous riots, some interviewees saw the disturbances in August 2011 as an opportunity to be part of the next chapter in the turbulent relations between the police and their communities:

[M]y granddad told me about the Broadwater Farm riots. My dad told me about the Brixton riots, and now, like, I can tell my son, my daughters about oh yeah, the riots that happened. So yeah. It's a piece of culture, I think it's a bit of culture to pass on'

[19-year-old male, mixed race, North London).

In a similar vein a young 17 -year-old, black man from Liverpool remembered:

My mum was happy with me, like, observing, 'cos she was in the first initial Toxteth riots in the eighties, so she wanted me to have, like, the same kind of memories.

Further evidence that poor police-community relations were an issue in the 2011 riots is derived the Metropolitan Police's Public Attitudes Survey (METPAS). This is a rolling survey conducted throughout the year, involving approximately 1,000 face-to-face interviews per month, or 12,000 a year. It uses a random sampling procedure, is representative of Londoners aged 16 and over, and asks a wide range of questions on experiences, perceptions and attitudes towards the police and crime. An analysis of the data immediately prior to the riots, and subsequently, found that respondents living in the London boroughs hit hardest by the disorder had substantially lower confidence in the police locally and London-wide prior to the disorder (and still did after). They also had substantially lower trust in police procedural fairness (treatment) and police community engagement prior to the disorder (and again after) (Hohl et al, 2012) these two measures being the ones the 'confidence model' identifies as the main drivers of overall confidence in the police (Stanko and Bradford, 2009; Jackson et al., 2013). Antagonistic police-community relations, both past and present, clearly shaped attitudes in those areas affected by rioting and, in the words of the rioters themselves, were a significant factor influencing not just their attitudes but also their conduct. The most common explanation given by many respondents for their attitudes toward the police focused on everyday negative experiences of policing and, more particularly, of the (mis)use of police powers.

\section{Treatment by the Police}

'..it was our chance to actually get back at the police. I've got personal reasons as well as what happened to that young lad in Tottenham.' [22 year old, white male, Birmingham]

As we have noted, in each of the cities where riots took place, running through the majority of interviews, respondents expressed considerable levels of antagonism towards the police. This varied in intensity - from poor relations and negative experiences on the one hand to an outright, visceral hatred on the other - but was audible everywhere. The roots of this hostility are complex. We suggested earlier that there are ways in which, perhaps particularly at times of significant upheaval, the police service become something of an easy substitute for other grievances and concerns. Certainly, a significant number of interviewees conflated 
their dislike of the police with concerns and frustration with unemployment, cuts, inequality and other problems for which the police could not in any sense be considered responsible. Nevertheless, it was also the case that, for many involved in the rioting, the police were a very deliberate and specific target. The origins of such feelings varied but, beyond the historically poor police-community relations and an inherited distrust of the police as an institution already mentioned, the more immediate reasons given coalesced around the poor treatment many respondents felt they received at the hands of the police. In this regard some talked about what they saw to be the general misuse of police powers, and the lack of accountability they felt attached to the police:

One young Black male gets killed every month, yeah, at the hands of the Police in the UK, yeah and I was glad that, you know, we're doing something about it now' [26 year old, white male, London]

For many others the accounts they gave focused much more particularly on the treatment they had personally experienced at the hands of the police. This, they argued, was a significant motivating force in much that occurred during the riots. As this 46-year old white man from Salford put it, 'I think it was more about having a go at the police, you know after years of abuse... because the police do abuse people, they do take liberties'. A similar sentiment was expressed by a 19-year-old Black student from Bromley who said:

Everything the police have done to us, did to us, was in our heads. That's what gave everyone their adrenaline to wanna fight the police....because of the way they treated us, we was fearless. And we was remorseless. Like we didn't care about whose house got burnt, like what shops got burnt, we didn't think about it...Same way they forget to think about us is the same was we forgot to think about them during the riots.

This narrative, that much of what occurred in the riots was a means of expressing a deep, often visceral anger toward the police, was articulated by respondents in all the areas the research covered: London, Birmingham, Manchester, Salford and Liverpool. It also came from respondents of all ages. Here a 17 year old Asian male from Tottenham describes his general feelings:

I hate the police. I don't hate the policing system, I hate the police on the street. I hate them from the bottom of my heart.

The same feelings, but here tied to slightly more specific experiences, come from a 29-year old black male from Westminster:

I've been beaten up in the back of one of them territorial support group war buses as we call them. These big black buses where they come and they kidnap us... And they beat us in there.... They're monsters. Absolute monsters. And they don't have no law and justice in their heart. They look at us. They look at us as scum.

Some claimed to have even anticipated the possibility of getting their own back, as in the case of one 16year-old black male student from Greenwich, who chased a police community support officer who had stopped and searched him before:

[I] started chasing him, because basically, it was pay-back, innit? We told him at the time when the riots will start we are gonna get you back one day. And that day was today man'. 


\section{Stop and Search}

They always wanna stop and search us all the time even without no reason they still wanna stop and search you for no reason. They do it to me every time I walk on the street, with my friends or by myself they always stop and search me. [18-year-old black male, northwest London]

In March 2012, a submission from London Youth to the Riots Communities and Victims Panel said: 'sadly, the police's trust and credibility among young people in areas affected remains close to zero... [youth workers] feel that stop and search is conducted in an unnecessarily demeaning manner and not necessarily intelligence-led' (Murphy, 2014). Subsequently the government's official Riots, Communities and Victims Panel's (2011) interim report explicitly linked trust in police to the exercise of Stop and Search powers, and emphasised that this was a particularly crucial issue for the police service. They concluded:

In many areas people identified stop and search (in relation to Black and Asian men) as a major source of discontent with the police. In some instances these tensions were cited as a motivating factor in the riots, including some of the attacks on the police. Some said that these powers are regularly used inappropriately, referencing the unprofessional way in which some officers undertake searches, but also the regularity of searches and the circumstances in which certain people are targeted. (2011: 64)

Of all the issues that the 'rioters' had with the police, it was stop and search that tended to figure most prominently in their accounts. In part, this is simply because being stopped and searched is undoubtedly the most common form of contact many such young people have with the police (Quinton, 2011). The large majority of our interviewees - reflecting what is known more broadly about those involved in the riots (Ministry of Justice, 2012) - were drawn from a section of society that generally has more contact with the police than the population at large, and whose experience and perception of both police officers and the police as an institution is disproportionately negative when compared with current public opinion (Jannson, 2006).

Descriptions of stop and search recurred with striking frequency and were most concentrated in responses from young, black males. Almost three quarters (73\%) of those interviewed said they had been stopped and searched in the last year, $71 \%$ more than once. Among young men the rate was much higher, and among young, black males a rate of twice a week or more was not uncommon. An 18-year-old black man from Lambeth expressed his frustration at this perceived harassment:

[T] hen something happens to you over and over again, like say I get arrested yeah, over and over again, and I get stopped and searched over and over again, and the police like keep trying to pick on me over and over again say cos I'm black, and I'm young... you just get to a point where you're fed up and can't take it no more.

He was far from alone and it is clear from the analysis of the 270 interviews that stop and search lay at the core of much anti-police feeling expressed. In the in-depth interviews, black respondents raised the issue stop and search more frequently than their white counterparts, though it was a common source of complaint regardless of the ethnicity of the respondent. Stop and search, though mentioned by respondents of all ages, was primarily an issue for younger people. Black respondents described feeling stereotyped by the police: being unfairly defined as gangs when walking around with friends and frequently stopped on what they saw as the fabricated or unsatisfactory premise of matching a description of a "black 
male'. Many attributed their regular experiences of stop and search to their ethnicity, as articulated by a 20-year-old man from Westminster who claimed to have been stopped 300 times in the last year, and said 'they stop us just for our skin colour'. This perception was echoed by those who had had little direct experience of stop and search themselves. A black 16-year-old young woman from Stockwell said: 'I think normally it's racism 'cause I don't see them do it to most white people', all I see is they mostly do it to black people... I see them walking past stopping black people every day'. This fed into a broader narrative of police racism that taints wider police-community relations in some areas but which, for young, black men in particular, was most often manifested in the practice of stop and search.

Interviewees often felt like they were continuously targeted in their local areas for little or no apparent reason, an impression that had rubbed off on other members of their communities. A 27 -year-old white woman from Salford said:

[Y]oung people in general cannot walk down the street without the police stopping them, you know, take your hat off, take your hood off, what you doing, empty your pockets, there's four of you, you've got to split up, you can't go round in a group, and em, even when they are not doing anything wrong, that kind of criminalises them.

Significantly, the umbrage expressed by interviewees appeared to focus less on the regularity with which they were stopped (though this was often resented) and rather was more concerned with police conduct during these interactions. Some respondents recounted instances of quite shocking violence; but more often they talked about the rudeness and aggression that they suggested frequently accompanied the practice. A 16-year-old boy from Birmingham described police officers hassling him and his friends on a regular basis while they played football:

They call us little shits and little bastards and everything. They're not what you see on the TV and that, acting all good and that, they can be bad people, I hate them.

Reflecting many of the findings from procedural justice research (Tyler, 2005; Bradford et al, 2014) these interactions were often coloured by experiences of disrespect and humiliation, which clearly fuelled a sense of antagonism, as in this account from a 19-year-old black man from Haringey in north London:

...they stop you and say, "ah there's been a reported robbery", or the same lame old excuse just to stop you and search you....and being rude to you for like, no reason, and just finding little things to arrest you for. They'll push you by purpose... Like they treat us horribly and then they don't understand like, they don't understand how we feel when we're getting treated like that.

A 22-year-old black man from Stockwell in South London, who said he had been stopped between 50 and 60 times in the last year, described feeling threatened by the way the police use stop and search:

[T]hese guys are always stopping us for no reason. Always. In their gangs... they're bullies. They'll jump out on me, batons out. That's threatening, that's intimidating me... I understand if you're doing your job you want to stop and search me, fair enough... but don't jump out of your car, it's like, it's like someone jumping out with a knife.

This young man acknowledged that stop and search may be a legitimate part of a police officer's role, and objected primarily to the way in which it was performed. A number of interviewees recalled positive 
interactions with particular officers, but such testimony was significant mainly because it was rare. A 22year-old white man in Birmingham, who said he had been stopped about 30 times in the last year, recounted a friendly relationship with a police officer who had arrested and stopped him several times:

[H]e's arrested me a few times, brilliant at his job, I don't know other coppers that good, he's really, really good at his job. But every time he speaks to me now, he stops me, and he asks me how I'm doing, he asks me what I'm doing and that... If every police officer was like him in the UK, the riots would never have happened.

Indeed, for a lot of interviewees, their negative experiences of stop and search epitomised the mutual hostility between the police and themselves, which was directly linked to their participation in the riots. Both the excessive use and the arrogance and aggression that were described as often characterising stop and search encounters were seen as representative of an abuse of power and a concomitant deficit of legitimacy. Without this legitimacy, many saw the police as existing solely to restrict their movements, or worse, to persecute them, and positioned them in a permanently adversarial role. A 17-year-old white student from north-west London explained his predicament:

We feel we can't walk down the street. We feel it's their [police] streets. We feel we can't do certain things because of like the actions they would take towards us and there's not a level of equality.

These feelings led many to see the riots as an opportunity to get their own back at the police, often recalling the short-lived sense of freedom and triumph examined in more detail below. As this 19-year-old mixed race man from Birmingham said:

Because they stopped me for no reason, I was getting pissed off, so I thought fuck it, now I'm getting back on them, and I felt even better, do you know what I mean? I don't know man, it works both ways. Treat someone the way you wanna be treated innit?'

\section{Empowerment and Revenge}

Just a lot of people in my area or South London have had bad experiences, experiences with the police ... And that was just their way of getting back at the police and having some kind of control. Cos when you're arrested, they can have the control, and they can talk to you how they want, do what they want. That day people could do what they wanted and say what they wanted to the police. And I think if they had the chance to do it again, they would.

As the 21 year old, mixed race woman from Clapham Junction, South London quoted above describes, for many caught up in the riots this was an opportunity for payback, for some sort of revenge against a police service they viewed with great hostility. At least one fifth of the 270 people interviewed for this study talked about their involvement in some form of action against the police. The majority of these spoke about their participation as retaliation for various perceived grievances. Linked to this many condemned looting and vandalism as devaluing or distracting attention from what they saw as a legitimate fight against an old adversary. Such interviewees stressed that their interest was in attacking the police and distanced themselves from the looting and vandalism that took place: 
My interests weren't really in looting... Where I come from there is a mentality that police are bad. Not call the police even if you need them. No statement, no talking. When we got the chance to vent anger at them, we took that chance', (17-year-old, Asian male, Ilford).

Rioters recounted how they sought revenge against the police. As one 34-year old, black male from Tottenham said:

After all the brutalising I have seen police doing to people it was a sweet moment, a sweet moment in my life to see police getting some of their own medicine'.

Many adopted the language of war when recalling the confrontation as they fought with the police in the streets. They described how they threw stones, bottles and other materials, rammed the police with wheelie bins and other things they could find to hand, and shouted 'Fuck the police'. Some spoke of how they targeted police property, setting fire to and vandalising cars, vans and police stations, or deliberately tried to inflict serious injury on officers. As anticipated by the social psychological literature on riots (Stott and Reicher, 1998) the experience of the 2011 riots for many of those heavily involved gave them a sense of empowerment as a result of a brief role reversal - momentarily experiencing the feeling of having the upper hand over the police. The excitement that this generated is palpable in many interviews. A 21-yearold, black British man from Brent who was involved in the rioting in north-east London said:

We had them under control. We had them under manners for once. They never had us under manners. We had them on lock. On smash. Running away from us. We weren't running from the police. They was the criminals today. We was enforcing the law. Getting them out of our town because they ain't doing nothing good anyway for no one.

This feeling of control was echoed by a 22-year-old white man who was involved in attacks on the police in Salford and Manchester:

It was buzzing to be honest, was really happy to be honest, 'cause we had total control of the precinct....we all hate them, we've all spent time in that police station, and you know it was ours for a day.

Interestingly, even some of those who did not target police officers or police property spoke about feeling empowered as a result of this rare show of police incapacity. A 15-year-old, white girl who looted in Clapham remembered:

For once it felt like you had so much power... it was the sense of power that shocked me. I've never seen police so scared before.

In Birmingham, a 16-year-old, Asian boy who also looted, similarly revelled in the freedom to do what he wanted, without the police stopping him:

We had power man. I felt like no one could stop us... it felt great, it felt, we could do what we wanted to do, we could break anything, we could do as much damage as we can, and we could not be stopped... Normally the police control us, like, the police have more power, we obey the law, the law was obeying us, know what I mean? 
This sense of power and, significantly, its apparent novelty for a large proportion of interviewees tied into wider feelings of exclusion experienced by many rioters (Ferguson, 2011; Taylor et al, 2011). While some respondents spoke about their participation in the riots in direct relation to their contact with police, others articulated an alienation from authority in general, including government and other, better off groups in society. This alienation was often manifested in feelings about police as representatives of a system from which many interviewees feel quite separate. When asked where anger towards police comes from, a 20-year-old, black man from Hackney responded:

[O]ur backgrounds, 'cause of where we're from, we're not really here, they won't talk to us, they don't listen to us.

In this context, participation in the riots was often explained as an expression of anger and frustration at this social invisibility, an outlet for those who felt they did not have access to other, more obviously legitimate channels of communication or complaint. Several respondents made this link between exclusion and rioting, as articulated by this 26-year-old, white man from Edmonton:

[W] hen no one cares about you, you're gonna eventually make them care, you're gonna cause a disturbance.

\section{Conclusion: 'The biggest gang'}

You don't really win fights against the police. You might win a few battles, but you don't win the war against them. In the long run. And they're a bigger, biggest gang on the road, to be honest. That's what the police are. Because they are bullies. (24-year-old, black male, Lewisham)

In the immediate aftermath of the riots, politicians and police spokespeople claimed that gangs played a crucial part in organising the disturbances ${ }^{9}$. This has now been generally refuted (Newburn et al, 2011), with a Home Office report released in October 2011 accepting that gangs did not, in fact, play a 'pivotal' role (Home Office, 2011). Indeed, Reading the Riots demonstrated that although individual gang members may have participated in the violence and looting, they rarely did so as part of an organised gang, and interviewees repeatedly noted that the most significant gang-related feature of the riots, was the suspension of hostilities between rivals for those few short days (Newburn et al, 2011). This was sometimes a pragmatic measure that enabled them to collaborate in looting or criminal damage, but was often spoken about specifically as a kind of spontaneous unity - in essence, and again borrowing the terminology of social psychology, the unity represented a developing, shared social identity: 'rioters' - in which those involved identified strongly with each and were generally united against the police. Whilst 'gangs' did not play the part in the riots that was suggested by politicians, the term 'gang' was used with some regularity by respondents in Reading the Riots. When asked about gangs many interviewees pointed to the police. One 21-year-old white man from Uxbridge, for example, said:

It's like the police, they're a gang. That's how people, like on the streets, that's how we see it... we say they're the biggest gang in the world.

A 26-year-old, black man from Croydon echoed this assessment:

${ }^{9}$ https://www.gov.uk/government/speeches/riots-theresa-mays-speech-on-11-august-2011 
[T]he police is the biggest gang going on road...The police is a gang. It's a gang controlled by the government. That's it. Funded by the government.

This phrase - 'the biggest gang' - and variations on it was used by a sizeable number of respondents. This, again, in our view reinforces one of the strongest themes emerging from the analysis of interviews with rioters: the sense that they were profoundly distrustful of the police, often viewed the police service monolithically as a single, hostile force, and against whom much of the rioting was directed. A great many of those interviewed as part of Reading the Riots talked very negatively about the police. As we have outlined, to a certain extent this reflected long-standing, embedded problems in police-community relations in certain parts of the country. For many there were also more particular and immediate experiences of mistreatment and prejudice at the hands of the police and a sense that they were constantly in conflict with this so-called 'biggest gang'. That this phrase recurred with such frequency, and in so many of the different areas in which there were riots, seems to suggest that it represents an established way of thinking about and understanding the police among certain social groups. Asked about the relations with the police many respondents talked of mistreatment, of harassment, and of what they perceived to be the misuse of police powers. As we have already highlighted, and to no great surprise given the wealth of existing research evidence (see, for example, Bowling and Phillips, 2007), Reading the Riots found stop and search to be a highly significant factor underpinning the hostility expressed by many of those involved in the riots toward the police. We conclude with three important points that were raised by the rioters' accounts, each of which is linked to their experiences of stop and search and more broadly to their attitudes toward policing.

First, over and above the perceived discrimination and disproportionality involved in police use of stop and search powers - and feelings of discrimination and targeting were significant issues - respondents tended to focus on the manner in which stops and searches were undertaken, highlighting the rude, sometimes aggressive and occasionally violent treatment they received. That some police officers behaved in this way reinforced feelings of relative powerlessness and impotence in the face of such treatment. From there it is a relatively short journey to aspects of the anger and frustration that were on view - in their most extreme form - during the riots. That ill-treatment in the course of stop and search seemingly occurred with relative impunity reinforced feelings of injustice, of moral double standards and added further fuel to the anger and frustration already generated by such encounters.

Second, stop and search was, in part, perceived as an issue of 'control'. In the way it was ordinarily used it was experienced as an attempt to regulate, to delimit the conduct of those regularly being stopped and, again, to do so in a way that was perceived to be unfair and/or discriminatory. This, in turn, led to considerable frustration, and no little anger in many cases. For some, involvement in the disorder was, briefly, an opportunity to attempt to reassert some sort of control, or to turn the tables on the police. The rioters' accounts are full of assertions that their conduct was, in part, 'revenge' for what they felt police officers had done to them, often regularly and over an extended period of time. More than that, however, it represented a fleeting opportunity to feel in control - in a world in which they often felt 'controlled' and, moreover, to feel that the tables had been turned on those who played such an important and resented regulatory role in their lives.

Finally, it is clear from the rioters' accounts that stop and search was important both in real terms (because of how it is experienced) and symbolically (because of what it has come to represent). Stop and search often involves confrontation, direct physical contact, and the potential for demeaning treatment. It has, over time, come to play a particularly important role in perceptions of policing in the round. That is to say, 
stop and search has come to represent something broader than street encounters with officers. The rioters' critical accounts of stop and search were translated directly into critical assessments of the police, and of police attitudes and conduct more generally. Over time stop and search has become something of a 'signal' matter (Innes, 2014) for particular groups of young people - young, black, inner-city males in particular (though not exclusively) - coming to stand for much, if not almost all, that they perceive to be wrong with the police. It is this, arguably, that makes stop and search such a toxic issue in relations between the police and particular groups and why it featured so prominently in rioters' accounts of their experiences of, and attitudes toward, the police. Consequently, to argue about whether stop and search powers represent a necessary policing tool, about whether such powers are used appropriately or not, and whether when used they are accompanied by courteous and professional behaviour by officers, whilst of course of undeniable importance, is nevertheless somewhat to miss the point in this context. The issue is that, as things stand, at least for some groups, stop and search is experienced and understood as an expression of the illegitimate, discriminatory, discourteous and unprofessional exercise of power by the police and, in the words of W.I. Thomas' famous sociological dictum, 'if men define things as real, they are real in their consequences' (Thomas and Thomas, 1928: $571-2^{10}$ ). Thus, whilst arguments about proportionality, 'available populations' and 'evidence-based stop and search' point to hugely important matters, they also miss one fundamental point, which is that the experience of stop and search does appear to be the cause of very considerable resentment and anger. As such, in the eyes of those involved in the rioting, stop and search and other forms of conduct by the police perceived to be unfair and lacking in legitimacy, were a significant contributory factor in the 2011 riots. It is important to repeat at this point that saying this is not to suggest that the riots were 'caused' by anger toward the police. Rather, the evidence from Reading the Riots suggests - and the events of 2011 were hardly the first riots of which this could be said - that anger toward the police was something that united many of those participating in the riots, and which sustained and even fuelled some of their actions.

Furthermore, it is important to reiterate, not least given the Guardian's front-page headline on the first day of publication of the results of Reading the Riots, that there is, of course, no suggestion that the rioting could somehow be reduced to 'anger with the police'. There was much else articulated during the four days of disorder, not least the frustration and injustice felt by those occupying precarious and marginal positions in an increasing perilous socio-economic environment. Moreover, the widespread looting that characterised significant elements of the disorder, particularly toward its latter stages, cannot be understood without some reference to the strength and power of the values of modern consumer capitalism (Bauman, 2012)). Equally, however, accounts of the riots that focus primarily on consumerism tend consequently to underplay both the violence in the riots, as well as the element of 'protest' that imbued the behaviour of many of those involved (Newburn et al, 2015). More particularly, such accounts tend very significantly to underplay the extent to which, particularly in the early stages of the rioting and at certain locations, frustration and anger with the police was a highly significant motivating and sustaining force in the disorder.

\footnotetext{
10 The attribution of the dictum to W.I. Thomas solely, despite the fact that the sentence appears in a book coauthored by Dorothy Swain Thomas, has been the subject of some controversy. The issue, and the rationale for the citation, is explained at its fullest in Merton (1995).
} 


\section{References}

Bauman, Z. (2011) The London Riots: On consumerism coming home to roost, http://www.socialeurope.eu/2011/08/the-london-riots-on-consumerism-coming-home-to-roost/

Body-Gendrot, S. (2013) Urban violence in France and England: comparing Paris (2005) and London (2011), Policing and Society, 23, 1, 6-25

Borch, C. (2006) The exclusion of the crowd: The destiny of a sociological figure of the irrational, European Journal of Social Theory, 9, 1, 83-102

Bowling, B. and Phillips, C. (2007) Disproportionate and discriminatory: reviewing the evidence on police stop and search, Modern Law Review, 70(6) 936-961

Bradford, B., Jackson, J. and Hough, M (2014) Police futures and legitimacy: redefining good policing In: Brown, Jennifer M., (ed.) The Future of Policing, London: Routledge

Campbell, B. (1993) Goliath: Britain's Dangerous Places, London: Methuen

Clare, J. (1987) The ratchet advances another turn, in Benyon, J. and Solomos, J. (eds) The Roots of Urban Unrest, Oxford: Pergamon Press

Edelman, M. (1964) The Symbolic Uses of Politics, Urbana: University of Illinois Press

Fassin, D. (2013) Enforcing Order: An ethnography of urban policing, Cambridge: Polity Press

Ferguson, B. (2011) Reading beyond the London riots: a city of two worlds, Guardian, $11^{\text {th }}$ December

Fielding, N. (2005) The Police and Social Conflict, London: Glasshouse Press

Fogelson, R.M. (1968) From resentment to confrontation: The police, the negroes, and the outbreak of the nineteen-sixties riots, Political Science Quarterly, LXXXIII, 2, 217-247

Gilje, P.A. (1999) Rioting in America, Bloomington: Indiana University Press

Guest, G.H., MacQueen, K.M. and Namey, E.E. (2012) Applied Thematic Analysis, Thousand Oaks, CA: Sage

Hohl, K., Stanko, E.A. and Newburn, T. (2012) The Effect of the 2011 London Disorder on Public Opinion of Police and Attitudes Towards Crime, Disorder, and Sentencing, Policing,

Home Affairs Committee (2011) Policing Large Scale Disorder: Lessons from the disturbances of August 2011, London: The Stationery Office HC 1456-I

Home Office, An Overview of Recorded Crimes and Arrests Resulting From Disorder Events in August 2011, October 2011 
Innes, M. (2014) Signal Crimes: Social reactions to crime, disorder and control, Oxford: Oxford University Press

Jackson, J., Bradford, B., Stanko, B. and Hohl K. (2013) Just Authority? Trust in the Police in England and Wales, Oxford: Routledge

Jansson, K. (2006) Black and Minority Ethnic groups' experiences and perceptions of crime, racially motivated crime and the police: findings from the 2004/05 British Crime Survey, Home Office Online Report $25 / 06$

Joshua, H. and Wallace, T. (1983) To Ride the Storm: The 1980 Bristol 'Riot' and the State, London: Heinemann

Keith, M. (1993) Race, Riots and Policing: Lore and disorder in a multi-racist society, London: UCL Press

King, M. (2013) Birmingham revisited - causal differences between the riots of 2011 and 2005? Policing and Society, 23, 1, 26-45

King, M. and Waddington, D. (2006) Flashpoints revisited: a critical application to the policing of antiglobalization protest, Policing and Society, 15, 3, 255-282

Lammy, D. (2011) Out of the Ashes: Britain After the Riots, London: Guardian Books

Le Bon, G. (1896) The Crowd: A study of the popular mind, London: T.F. Unwin

Lewis, P. and Newburn, T. (2011) Reading the Riots: Our methodology explained, Guardian, $5^{\text {th }}$ December, http://www.theguardian.com/uk/2011/dec/05/reading-the-riots-methodology-explained

Lewis, P., Newburn, T., Taylor, M. and Ball, J. (2011) Blame the police: why the rioters said they took part, Guardian, $5^{\text {th }}$ December

Merton, R.K. (1995) The Thomas Theorem and the Matthew Effect, Social Forces, 74, 2, 379-424

Metropolitan Police Service (2012) Four Days in August, London: Metropolitan Police

Ministry of Justice (2012) Statistical Bulletin on the Public Disorder of $6^{\text {th }}-9^{\text {th }}$ August 2011, London:

Ministry of Justice

Morrell, G., Scott, S., McNeish, D. and Webster, S. (2011) The August Riots in England: Understanding the involvement of young people, London: NatCen

Murphy, S. (2014) Rethinking Stop and Search: Theresa May, Section 60 and the 'ways of thinking' about marginalised youth, [Online] Available at: http://youththink.wordpress.com/2014/02/10/rethinking-stopand-search-theresa-may-section-60-and-the-ways-of-thinking-about-marginalised-youth

National Advisory Commission on Civil Disorders (1968) The Kerner Report: The 1968 Report of the National Advisory Commission on Civil Disorders, New York: Pantheon 
Newburn, T. (2015) Reflections on why riots don't happen, Theoretical Criminology,

Newburn, T., Cooper, K., Deacon, R. and Diski, B. (2015) Shopping for free? Looting, consumerism and the 2011 riots, British Journal of Criminology

Newburn, T., Topping, A., Ferguson, B. and Taylor, M. (2011) The four day truce: gangs suspended hostilities during the riots, Guardian $6^{\text {th }}$ December

North London Citizens (2012) Citizens' Inquiry into the Tottenham Riots, London: London Citizens

Pemberton, S. (2008) Demystifying Deaths in Police Custody: Challenging State Talk, Social \& Legal Studies, $17,2,237-262$

Quinton, P. (2011) The formation of suspicions: police stop and search practices in England and Wales, Policing and Society, 21, 4, 357-368

Police Federation, Policing the riots: Police Federation of England and Wales response and recommendations, December 2011 (accessed 5 June 2012)

Reicher, S. (1984) The St Pauls' riot: An explanation of the limits of crowd action in terms of a social identity model, European Journal of Social Psychology, 14, 1-21

Reicher, S. (1987) Crowd behaviour as social action, in Turner, J.C. (ed) Rediscovering the Social Group: A self-categorization theory, Oxford: Basil Blackwell

Roche, S. and de Maillard, J. (2009) Crisis in policing: The French rioting of 2005, Policing, 3, 1, 34-40

Riots Communities and Victims Panel (2011) Five Days in August, Interim report, London: Riots, Communities and Victims Panel

Riots Communities and Victims Panel (2012) After the Riots, Final Report, London: Riots, Communities and Victims Panel

Rock, P. (1981) Rioting, London Review of Books, 17-30 September

Scarman, Lord Justice (1981) The Scarman Report: The Brixton Disorders 10-12 April 1981, Harmondsworth: Penguin

Scraton, P. (2002) Lost lives: hidden voices: 'Truth' and controversial deaths, Race \& Class, 44, 1, 107-118

Sergeant, E., Murphy, K. and Cherney, A. (2014) Ethnicity, trust and co-operation with the police: Testing the dominance of the process-based model, European Journal of Criminology, 11, 4, 500-524

Smith, D.J. (1987) Policing and urban unrest, in Benyon, J. and Solomos, J. (eds) The Roots of Urban Unrest, Oxford: Pergamon Press

Smith, D.J. (1991) The origins of black hostility to the police, Policing and Society, 2, 1, 1-15 
Stanko, E. and Bradford, B. (2009) Beyond Measuring "How Good a Job" Police Are Doing: The MPS Model of Confidence in Policing. Policing: A Journal of Policy and Practice,3 (4):322-330

Stott, C. and Drury, C. (2000) Crowds, context and identity: dynamic categorization processes in the 'poll tax riot', Human Relations, 53, 2, 247-273

Stott, C. and Reicher, C. (1998) How Conflict Escalates: The Inter-Group Dynamics of Collective Football Crowd 'Violence', Sociology, 32, 2, 353-377

Sykes, G.M. and Matza, D. (1957) Techniques of neutralization: a theory of delinquency, American Sociological Review, 22, 6, 664-670

Tarde, G. (1962) The Laws of Imitation, Gloucester, MA: Peter Smith

Taylor, M., Rogers, S. and Lewis, P. (2011) England rioters: young, poor and unemployed, Guardian $18^{\text {th }}$ August

Thomas, W.I. and Thomas, D.S. (1928) The Child in America: Behaviour problems and programs, New York: Knopf

Tyler, T. (2005) Policing in black and white: Ethnic group differences in trust and confidence in the police, Police Quarterly, 8, 3, 322-342

Waddington, D. (1992) Contemporary Issues in Public Disorder, London: Routledge

Waddington, D., Jones, K. and Critcher, C. (1989) Flashpoints: Studies in public disorder, London: Routledge

Waddington, D. and King, M. (2005) The Disorderly Crowd: From Classical Psychological Reductionism to Socio-Contextual Theory - The Impact on Public Order Policing Strategies, Howard Journal, 44, 5, 490-503

Waddington, P.A.J. (1991) The Strong Arm of the Law, Oxford: Oxford University Press

Waddington, P.A.J. (1994) Liberty and Order: Public order policing in a capital city, London: UCL Press 